A highlight of the 2nd South African AIDS Conference was the first Nkosi Johnson Memorial Lecture, delivered by Dr Mamphela Ramphele. Nkosi Johnson, young man that he was, warmed all our hearts when he courageously spoke out against discrimination at the World AIDS conference in Durban 2000. This lecture will be a consistent feature of the SA HIV Conference, to mark this young man's role in ridding South Africa of HIV-related discrimination. Dr Ramphele, a notable academic, activist and fine South African, gave a stirring and thought-provoking lecture that really set the tone for the conference. Unity and accountability demands that we take stock and examine ourselves critically and honestly. It is our pleasure to publish the First Nkosi Johnson Memorial Lecture as delivered on 7 June 2005.

\section{HIV/AIDS: THE MIRROR IN SOUTH AFRICA'S FACE}

Let us open with Nkosi Johnson's words of wisdom:

I want people to understand about AIDS - to be careful and respect AIDS - you can't get AIDS if you touch, hug, kiss, hold hands with someone who is infected. Care for us and accept us - we are human beings. We are normal. We have hands. We have feet. We can walk, we can talk, we have needs just like everyone else - don't be afraid of us - we are all the same!'

Why would an 11-year-old child have to make such an impassionate plea in the South Africa of 2000? Is this not a society that has committed itself to the fundamental human rights enshrined in the UN Charter? Is this not a society that prides itself in adhering to the African value system of Ubuntu? Is this not a country with a government that has explicitly stated that its governance principles are based on 'Batho Pele' (People First)? What has gone wrong?

HIVIAIDS is a mirror in the face of our society. It forces us to examine the contours of our face as it really is, not as we would like to see it. Like any face, ours bears the scars of the past, the impact of the realities of today and indications of how the future is likely to shape up for us. Let us take each in turn.

\section{HIV/AIDS and the past}

The old adage 'the chickens are coming home to roost' has a particularly cruel twist to it for South Africa as a society. There are just too many chickens coming home to roost on our fragile democratic edifice. We were dealt too bad a hand by history. Just think of the legacy we have to cope with which has contributed to our vulnerability to the HIVIAIDS pandemic. That legacy also undermines our capacity to address the pandemic decisively.
First, the foundations of our society are built on conquest that undermined the structure and socioeconomic fabric of indigenous people and constrained their ability to adapt and evolve to meet the challenges of modernity. Adherence to cultural and customary practices that may be in conflict with the values of science in areas where universally accepted practices save lives, might be seen as the only way to protect and defend the dignity of a wounded people. We have elements of this way of thinking in our society.

Second, the migrant labour system and its disruptive impact on family life over generations have undermined the dignity of people housed in migrant labour hostels. This system is a major contributor to the size and shape of the HIV/AIDS pandemic in our society. Denial of the rights of migrants to dignified lives with their families made them vulnerable to sexually transmitted diseases. It turned men into conduits of the infection to their families.

Third, the pressures of the struggle against apartheid and the brutal suppression of the liberation movement forced many into exile. Life in exile made many vulnerable to contact with and infection by the virus, which had its early manifestations in some of the frontline states where many of the heroes of the struggle lived. It is indeed a cruel irony that returning heroes should have been conduits of this deadly virus.

Fourth, the illegitimacy of the apartheid state made it unwilling or unable to tackle the HIVIAIDS pandemic in its infancy in the 1980s when it could have been nipped in the bud. We know from experiences of much poorer countries that implementation of a comprehensive care and treatment programme at a stage when the infection rate was low contained its spread, to less than 3\% to date in Senegal, for example.

HIVIAIDS is one of the many costs of the legacy of apartheid. Apartheid was an expensive experiment. It demonstrated beyond doubt that inequality is expensive, not just for those discriminated against, but for society as a whole.

\section{HIV/AIDS and the present}

The ideals we signed up for as a post-apartheid society are enshrined in our Constitution. The gap between those ideals and our practices as a society is large. Ours is a Constitution second to none in enunciating commitments to the fundamental rights of everyone. The rights of the child. Equality between men and women. And the responsibility of the state to ensure that the basic socioeconomic rights of citizens are enabled.

There are a number of reasons for this large and in some areas growing gap. First of these is the difficulty of overcoming the 
legacy of inequality. Policy commitments are often not followed through into implementation, monitoring and evaluation. Much of the problem comes from the weak implementation capacity of the government machinery at all levels of government, as acknowledged by the President in his State of the Nation address earlier this year. There are notable exceptions. Denial of opportunities for management training and experience in the past, and the failure to acknowledge and correct deficits since 1994, have left us in a weak position to live out our commitments.

Second, there is the 'Shouting Silence' that Xoliswa's documentary speaks to. Xoliswa was moved by her personal loss of her own mother to the pandemic to document the harrowing lives of young people left to fend for themselves following the deaths of their mothers from HIVIAIDS. The loneliness of children walking the streets in search of love and care is forcefully brought home to us. The heroic efforts of grandmothers who come out of their retirement to become both mothers and fathers to their orphaned grandchildren are captured sensitively in this documentary. We know of many more poor women all over our country who are rising to the challenge in the face of great adversity.

But why the deafening silence from the rest of us? Why did we have to be reminded by Nkosi to 'care for us and accept us we are human beings'? Where is Ubuntu of the whole society in the face of the estimated more than 5 million South Africans living with HIVIAIDS under the cloud of stigma? Where was Ubuntu when many of the 300000 people who died in 2004 from HIVIAIDS did so without the comfort of loved ones because of the shame they felt? Where is Ubuntu when close to 1000 people in the prime of their lives (15 - 49 years of age) die miserable deaths each day, shielding from the sting of stigma that still pervades our society and constrains our response to the pandemic? Where is Ubuntu when the caregivers of orphans and vulnerable children are not able to access child support grants because of uncaring and corrupt officials? Where is Ubuntu when children are sexually assaulted by their fathers and other close relatives? Where is Ubuntu when babies are raped in the vain hope of cleansing infected men of HIVIAIDS?

We are all challenged by the level of pain and suffering of people living with HIV/AIDS and their caregivers to stop paying lip service to the values and precepts enshrined in our Constitution. The quality of our society will be judged by how we treat the most vulnerable among us. We are not at the moment doing well on that score.

Third, part of the reason for the silence is our embarrassment about acknowledging the reality of HIV/AIDS, given its links to sexuality. We are a socially conservative society. All the cultures we bring into the new South Africa are prudish about talking about sex. We just do it. But we have to talk about sex as President Museveni of Uganda did, and made it part of the responsibility of government officials to do the same. Captains of industry and commerce must also step up and lead AIDS campaigns with the same passion they devote to profits. AIDS affects the bottom line by undermining the quality of our human capital. Combating HIV/AIDS has to involve a comprehensive approach that includes changing behaviours, including the practices that make men and women more vulnerable to infection.

Fourth, the clash between customs that create a breeding ground for sexually transmitted diseases, including HIVIAIDS, and the demands of combating the pandemic have to be acknowledged and challenged. Polygamy and multiple sexual partners, inheriting widows, unprotected sex, non-sterile initiation rites etc. all have to give way to safer practices. There is just too much at stake for us to let customs continue to put people at risk.

Finally, there is a cruel irony in that of all African countries affected by HIV/AIDS South Africa has the greatest ability to combat the disease, yet we are under-performing. Why? How do we explain Brazil's better performance with more or less the same level of scientific proficiency and economic development? We have a serious problem of mistrust in our society that prevents us from acknowledging our problems and using the resources we have to address them.

Take the case of the causation of HIV/AIDS. Why did it take so long to have clarity infusing our policy responses? We have the depth of scientific know-how and economic resources to have been a front-runner in comprehensive care and treatment and deal a mortal blow to the disease, as Brazil did. But the scientists were largely white, male, urban based, and outside the policy-making domain of government. Mistrust of the racist system that denied the majority of South Africans scientific literacy and proficiency, constrained evidence-based policy-making.

To add insult to injury, the same racist system had over centuries in many parts of the world stigmatised black male sexuality as dangerous and driven by uncontrollable lust. Unless we acknowledge the pain of those so stigmatised, we are unlikely to overcome our mistrust and build a better life for all. But those wounded by the past also need to transcend the past and take ownership of shaping a future of dignity for all. 'The reconstruction of the soul', as former President Mandela reminds Us, is still unfinished business in South Africa.

Scientists must stand up more and often to say no to those bent on misleading the public. This is particularly important in a society with such low levels of literacy, numeracy and understanding of established basic scientific facts including how our bodies function. Confusing advice to those already overwhelmed by the trauma of HIVIAIDS should not be permitted. The highest ethical standards should be upheld in the care and treatment of HIVIAIDS-affected people and in clinical trials involving them.

The medical profession needs to play the role of watchdog for poor and vulnerable people. The South African Medical Association should be at the forefront of the protection campaign. Silence makes all of us accomplices. How can we 
allow confusion between the role of specific treatment with antiretrovirals on one hand, and the benefits of good nutrition and supplementary nutritional agents such as vitamins for any health care process on the other? It sounds so medieval. Remember the sanatoria of pre-industrial Europe where many died of tuberculosis before the advent of antimycobacterial remedies? Remember that those early TB drugs too had toxic side-effects - but they were better than placebos? Toxicity diminished with better drugs invented later with the benefit of better knowledge. Why are we not drawing on rich medical history to help our society cope with this present challenge?

\section{The way forward}

The best way of honouring the memory of Nkosi Johnson and many other children who met premature deaths at the hands of HIV/AIDS is to end denialism now. Our democracy is over ten years old now; we need to take ownership of shaping our country's future and create a better life for all. Blaming apartheid has its limits, just as blaming one's parents for one's failures has its limits too. We need to transcend our past and build a better future by playing to our strengths and minimising our weaknesses.

We need to promote a rights-based value system in our society at all levels. The President and his Cabinet should lead the charge on this. No government official should be allowed to undermine the rights of citizens without being held accountable. Official acts of omission or commission and institutional arrangements that infringe on the rights of people should be tackled urgently. For example, overcrowded prisons and failing public services undermine what our society stands for.
Education and training programmes for all public officials is of key importance, and public education programmes, including school-based ones, should be vigorously promoted too. Men need to be educated about the difference between manhood and male dominance. Real men do not need to violate the rights of women and children to assert their manhood. Women need to be part of the teaching and learning of husbands, sons, brothers and significant others about gender relationships in a human rights culture. It is only when a critical mass of citizens is confident enough to demand their rights that a human rights culture will flourish. In such a flourishing human rights culture, accountability of public officials will be better enforced.

We need to enforce the rights of citizens, especially the vulnerable ones. It is a sad reality that law enforcement agencies do not yet see human rights violations as a crime. Domestic violence is still treated as a private affair even as the rights of women and children are violated. Recent reports of the epidemic of violence against women and children add urgency to this issue. Training and linking incentives to enforcement of rights is urgently needed in our law enforcement system. There must also be penalties for failure to perform in this area.

Those citizens who are enlightened have a responsibility not only to demand their rights, but also to ensure that the rights of the least in our society are respected and protected. Only then can we call ourselves a civilised country. Only then will we have honoured the memory of Nkosi.

\section{MAMPHELA RAMPHELE}

7 June 2005 